\title{
Developing Computer Network Based on EIGRP Performance Comparison and OSPF
}

\author{
Lalu Zazuli Azhar Mardedi \\ Academy of Information Management and Computer \\ AIMC Mataram \\ Mataram, Indonesia
}

\author{
Abidarin Rosidi \\ School of Information Management and Computer \\ STMIK Yogyakarta \\ Yogyakarta, Indonesia
}

\begin{abstract}
One of the computer network systems technologies that are growing rapidly at this time is internet. In building the networks, a routing mechanism is needed to integrate the entire computer with a high degree of flexibility. Routing is a major part in giving a performance to the network. With many existing routing protocols, network administrators need a reference comparison of the performance of each type of the routing protocol. One such routing is Enhanced Interior Gateway Routing Protocol (EIGRP) and Open Shortest Path First (OSPF). This paper only focuses on the performance of both the routing protocol on the network topology hybrid. Network services existing internet access speeds average of $8.0 \mathrm{~KB} / \mathrm{sec}$ and $2 \mathrm{MB}$ bandwidth. A backbone network is used by two academies, they are Academy of Information Management and Computer (AIMC) and Academy of Secretary and Management (ASM), with 2041 clients and it caused slow internet access. To solve the problems, the analysis and comparison of performance between the Enhanced Interior Gateway Routing Protocol (EIGRP) and Open Shortest Path First (OSPF) will be applied. Simulation software Cisco Packet Tracer 6.0.1 is used to get the value and to verify the results of its use.
\end{abstract}

Keywords-Network; EIGRP; OSPF; based; simulator; performance

\section{INTRODUCTION}

The use of computer networks in everyday lives is increasingly high. It is due to the various facilities offered by the network, ranging from the ease of communicating to the possibility of sharing resources. The use of the requires a variety of tools, such as routers and switches as well as an understanding of the various techniques (addressing technique using the IP address and routing techniques. Routing is the process of sending data packets from the host of origin to the destination host, which is performed by the routers [1].

One form of computer network system usage is an internet connection. To build an internet network, it requires some hardware, software, and protocols. TCP / IP is a protocol standard that is applied to the Internet. The existence of a router in the network TCP / IP is very important. It is due to a large number of hosts and differences in the devices used on the network TCP / IP. As a result, it takes a routing mechanism that can integrate millions of computers with a high degree of flexibility. Routing is divided into two categories; they are static routing and dynamic routing [2].

Computer network expansion will certainly have an impact on the quality of the Internet connection service and connection of existing data exchange [3]. In 2003 the existing Internet connection is only used by the Academic Unit and the
Finance Department at the Academy of Information Management and Computer (AIMC) and Academy of Secretary and Management (ASM). However, in 20151 backbone and bandwidth $2 \mathrm{MB}$ with Mikrotik routers, computer network services are already used by these academies. Computer network service at those academies is faculty, students and staff with 1021 clients that accesses the computer network, while the other can be accessed by a client in 1020 is comprised of faculty, students, and staff. The uses of computer networks by these two academies reach 2041 clients that access the computer network service every day.

With the conditions of using one backbone by two academies of speed in accessing the Internet an average of 8.0 $\mathrm{KB} / \mathrm{sec}$ if the network was accessed by a client in 2041. The needs to be a strategy that is mature in conducting development by reference to the comparison of performance between EIGRP to OSPF about which one is better, so that each user gets good access to share and access the data to the internet with the best connection. EIGRP and OSPF routing protocol is a kind of underdog this time [3]. To determine the effectiveness of the distribution of bandwidth, this paper will discuss on a better performance comparison between EIGRP and OSPF on computer network services at AIMC and ASM. With the goal of producing a best development design system of computer networks, it can be implemented in existing computer networks at those academies.

\section{LITERATURE REVIEW}

\section{A. Routing Protocol}

A routing protocol is a set of rules or standards that determine how the router on the network to communicate and exchange information with one another, allowing them to choose the best route to the destination network. Routing protocols perform several activities, including:

1) Network discovery.

2) Update and maintain the routing table.

There are three types of methods used by the routing protocol, they are:

\section{1) Distance Vector (Path Vector) Protocol}

It is known as the determination of distance vector routing protocol based on distance or the shortest distance between the points of origin of the package with the destination point. [2]

\section{2) Link State Protocol}


It is called link state routing protocol for the determination made based on information obtained from other routers. [2]

3) Ring

Ring protocol uses aspects of distance-vector routing protocol types and link state. Examples ring is EIGRP. [2]

\section{B. Open Shortest Path First (OSPF)}

OSPF is a link-state routing protocol (LS), which is based on open standards. Each router is configured to use a link-state routing protocol will send two kinds of packages, namely:

1) LSR (Link-State Refreshment) are sent periodically to the router that are around to see if the router is still active and still form a link to the router.

2) LSA (Link-State Advertisement) or routing updates are sent only when there is a change on the network and at the start (initialization).

At first, OSPF router is turned on, and then the router will send a multicast LSA. The router that receives the LSA will copy the information it carries, then pass (forward) of the LSA. Information obtained from the LSA will be stored in the topological (link-state) database. Based on LSA and also the topological database that contains all existing routers on the network, each router will run the SPF algorithm and form the SPF Tree. [1]

\section{Enhanced Interior Gateway Routing Protocol (EIGRP)}

A routing protocol owned by Cisco that works on routers and the internal route processors contained in the core layer switches and distribution layer switches Cisco. EIGRP is a distance vector protocol that classes and enhanced.

EIGRP has the following characteristics:

1) Using the cost of load balancing are not the same.

2) Using a combination of a distance-vector algorithm with link-state.

3) Using Diffusing Update Algorithm (DUAL) to calculate the shortest path.

4) Supporting IP, IPX, and AppleTalk through modules that are dependent protocol. [2]

\section{Switch}

It is a device that filters and missed packets of an LAN. Switcher works at the data link layer (layer 2) and sometimes in the Network Layer (Layer 3) based on the OSI reference model that can work for any protocol packets. LANs that use switches to communicate on the network then called Switched LAN or in the physical Ethernet network called Switched Ethernet LANs.

The switch has almost the same function as a hub. The difference is that the switch can operate in a full-duplex mode and can track and filter information transferred to and from specific destinations, while the hub cannot filter and divert the path of relationships. [1]

\section{RESEARCH METHOD}

\section{A. Development Method}

1) Need Analysis
It is a process of finding the problem and generates alternative solutions to problems that are relevant.

2) Designing

It is the first step in manufacturing phase and or development of systems for each product system. At this stage of the design will be produced which will be built.

3) Modeling

At this stage, it will do the design that was made on a limited scale so that it becomes integrated into more useful work.

\section{4) Examination}

This stage is the most critical element of the overall process design and process modeling that has been done. At this stage will be discussed basic - basic trial design and the model that essentially is a collection of techniques used to conduct trials according issues tailored to the problems and objectives as a whole.

\section{B. Research Setting}

This research was conducted at the Academy of Information Management and Computer and Academy Management Secretary Mataram. This study begins with an ongoing problem, namely 1 backbone with bandwidth of 2 MB is accessible by 2 colleges such as Academy of Management Computer and Academy of Secretary and Management Mataram.

\section{Data Collecting Techniques}

1) Observation

Direct observation and attention to and examine the computer network services in the Academy of Information Management and Computer and Academy of Secretary and Management Mataram. Observations were done on the computer network and the data collected are as follows:

a) Computer network conditions,

b) Computer network data used,

c) Data traffic of computer networks by observing the delay and timing parameters such as convergence.

\section{d) Computer network development plan.}

The data above will be used as the basis for developing the computer network at the Academy of Information Management and Computer and Academy of Secretary and Management Mataram.

\section{Need Analysis}

In this phase, the basis or foundation of research on the development of computer network design at the Academy of Information Management and Computer (AIMC) and Academy of Secretary and Management (ASM) Mataram. In this case, an analysis of all the data that already collected in finding the problem and generate alternative solutions to the existing problems in order to achieve the ultimate goal of this research is to meet the needs of users in making interactions within the computer network at those colleges. Problems and alternative solutions resulting in this stage will be used as a basis for the next research step. 


\section{E. Stage Design}

1) Old Schematic

In the old scheme, the writer will explain the existing network at Academy of Information Management and Computer (AIMC) and Academy of Secretary and Management (ASM) Mataram. A backbone network access service is used by these two academies. The number of clients who access the internet, namely 2041 client so that the speed of access reached $8.0 \mathrm{~KB} / \mathrm{sec}$. Fig 1 is an old schematic network.

The network use at the Academy of Information Management and Computer (AIMC) and Academy of Secretary and Management (ASM) Mataram, includes the overall activities or academic activities such as students, staff, faculty and leadership. Where network services accessed by the client in 2041 consisting of those academies in order that the speed in accessing such downloads reached $8.0 \mathrm{~KB} / \mathrm{sec}$. Figure 2 is showed a schematic end user.

\section{2) New Scheme}

The need for network implementation that can vary in each location to make a difference in the type and amount of equipment needed. Differences in the type and number of these tools as well that ultimately make the difference in techniques and methods to obtain the information required by the router, as one of the tools for routing in the network. The use of many routers make network administrators choose to use a routing protocol as a way for the router to get the information to do the routing.

\section{a) Network Design Flowchart}

In this study explained how the simulation system design and configuration of the data communication network based on ring topology using EIGRP and OSPF routing protocol. Fig. 3 showed a flowchart network design.

Fig. 3 showed the stages in the design and simulation performance of EIGRP and OSPF in a ring topology. This simulation is done on a Packet Tracer 6.0.1 software and configure the network begins with the manufacture of the network topology is a ring topology, setting IP Address, and IP settings on each interface. Each topology configured by the EIGRP and OSPF routing protocol then conducted tests ping to every existing PCs after work then proceed to the analysis.

\section{a) Network Topology}

In this study, the software used for the simulation is a Cisco Packet Tracer 6.0.1 provides a development environment performance communications networks. On this design will be applied a backbone that is used by the two academies (AIMC and ASM) Mataram. Networks that want to implement only comparing the performance of the OSPF with EIGRP routing protocol.

The topology to be used in this simulation is by using a ring topology with 3 pieces each router, 4 pieces of switches, and eight PCs for every topology and routing protocol. Fig. 4 showed a network topology.

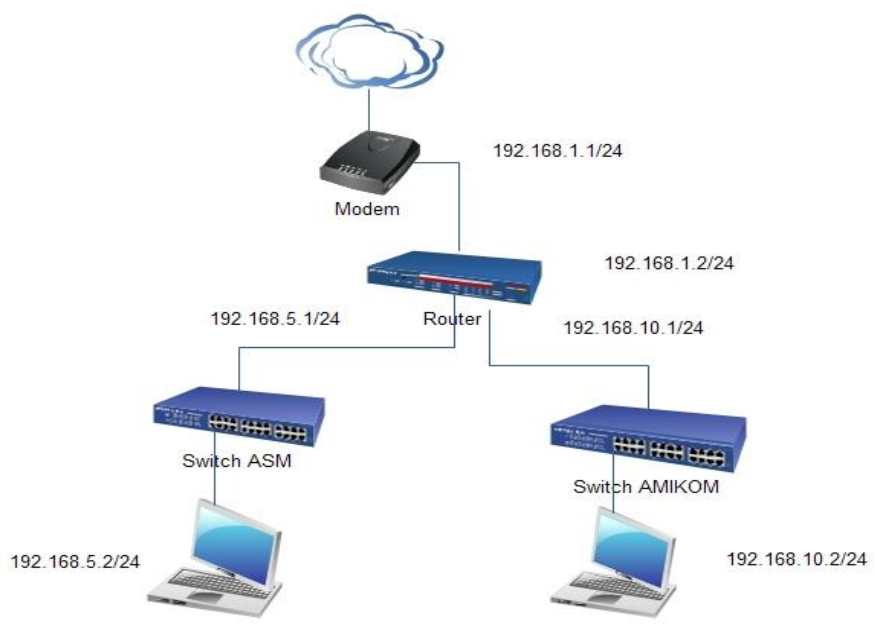

Fig. 1. Old Schematic

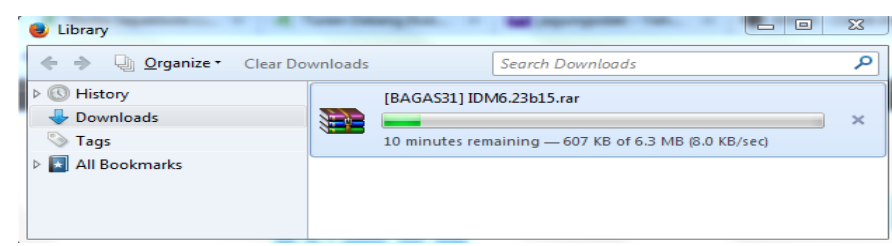

Fig. 2. End user

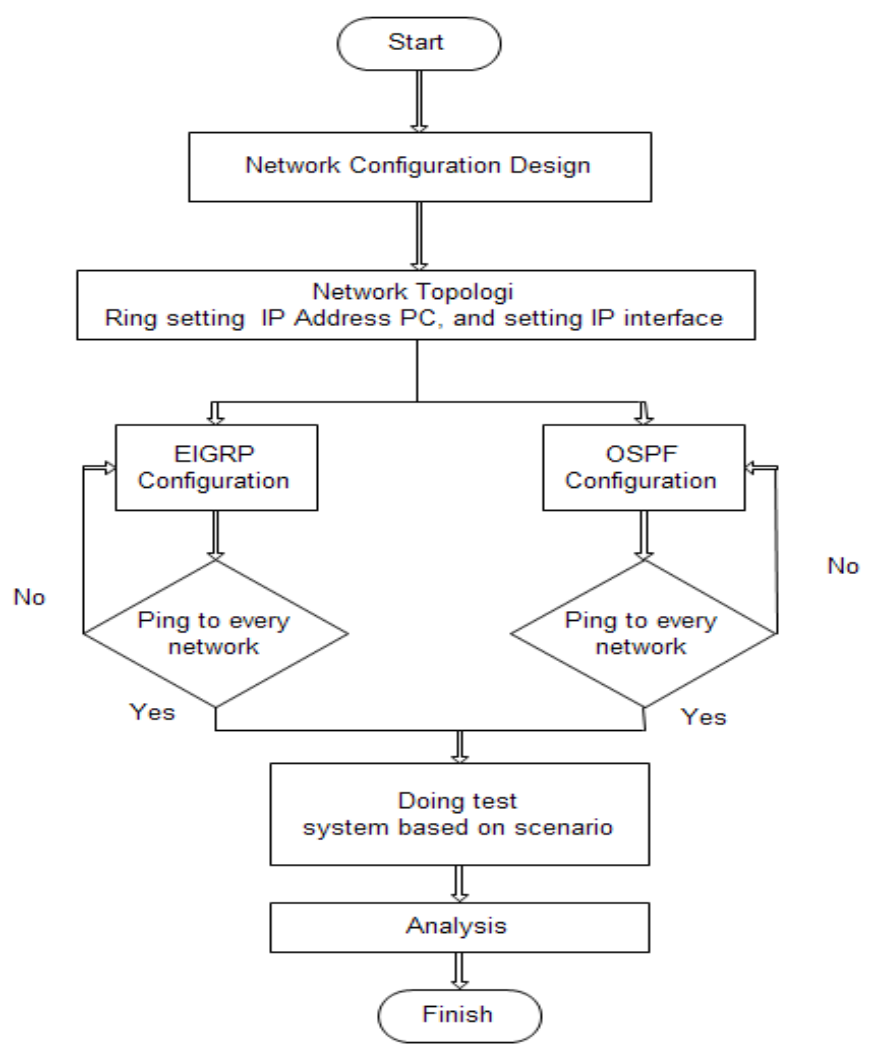

Fig. 3. Flowchart network design 


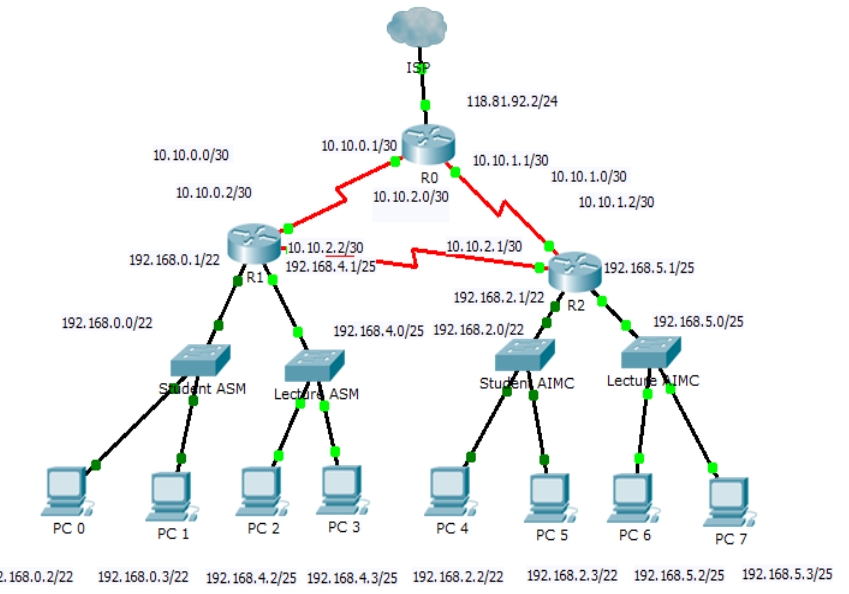

Fig. 4. Network topology

\section{b) IP Address Calculation}

At this stage, it will be sub netting based on the number of existing networks as much as 7 network i.e. from R0 to R1, R0 to R2, R1 to R2, students' networks for ASM, lecturers' network, and students and lecturers of AIMC. The network address of each network is as follows:

TABLE I. NETWORK ADDRESS

\begin{tabular}{|l|l|}
\hline Network Name & Network Address \\
\hline R0 to R1 & $10.10 .0 .0 / 30$ \\
\hline R0 to R2 & $10.10 .1 .0 / 30$ \\
\hline R1 to R2 & $10.10 .2 .0 / 30$ \\
\hline ASM Student Network & $192.168 .0 .0 / 22$ \\
\hline ASM Lecture Network & $192.168 .1 .0 / 25$ \\
\hline AIMC Student Network & $192.168 .2 .0 / 22$ \\
\hline AIMC Lecture Network & $192.168 .3 .0 / 25$ \\
\hline
\end{tabular}

- Ring topology

$2^{\mathrm{n}} \geq \times, \mathrm{n}$ is the number of binary 1 in the subnet mask that must be added in order to exceed or equal the number of required network whereas $\mathrm{x}$ is the number of the required number of subnets on a network so that the equation becomes:

$$
\begin{aligned}
& 2^{\mathrm{n}} \geq x \\
& 2^{\mathrm{n}} \geq 8 \\
& \text { If } \mathrm{n}=3 \text { then, } \\
& 8 \geq 8 \\
& \mathrm{By} \text { adding } 3 \text { bits in the subnet mask } \\
& 255.255 .255 .0 / 24 \\
& 1111111.11111111 .11111111 .11100000 / 27
\end{aligned}
$$

$$
255 \text {. } \quad 255 \text {. } 255 \quad \text {. } 254 \quad / 27
$$

The total amount deducted hosts 256224 of the amount above calculation becomes the difference or range of IP addresses that can be used for each subnet, 256-224 $=32$.
TABLE II. CALCULATION IP ADDRESS

\begin{tabular}{|l|l|l|l|l|}
\hline $\begin{array}{l}\text { Subnet } \\
\text { Number }\end{array}$ & IP Address & $\begin{array}{l}\text { Network } \\
\text { Address }\end{array}$ & $\begin{array}{l}\text { Broadcast } \\
\text { Address }\end{array}$ & Subnet mask \\
\hline SN 1 & $\begin{array}{l}10.10 .0 .1- \\
10.0 .0 .2\end{array}$ & 10.10 .0 .0 & 10.10 .0 .3 & 255.255 .255 .252 \\
\hline SN 2 & $\begin{array}{l}10.10 .1 .1- \\
10.0 .0 .2\end{array}$ & 10.10 .1 .0 & 10.10 .1 .3 & 255.255 .255 .252 \\
\hline SN 3 & $\begin{array}{l}10.10 .2 .1- \\
10.0 .0 .2\end{array}$ & 10.10 .2 .0 & 10.10 .2 .3 & 255.255 .255 .252 \\
\hline SN 4 & $\begin{array}{l}192.168 .0 .1- \\
192.168 .3 .254\end{array}$ & 192.168 .0 .0 & 192.168 .3 .255 & 255.255 .252 .0 \\
\hline SN 5 & $\begin{array}{l}192.168 .1 .1- \\
192.168 .1 .126\end{array}$ & 192.168 .1 .0 & 192.168 .1 .127 & 255.255 .255 .128 \\
\hline SN 6 & $\begin{array}{l}192.168 .2 .1- \\
192.168 .3 .254\end{array}$ & 192.168 .2 .0 & 192.168 .3 .255 & 255.255 .252 .0 \\
\hline SN 7 & $\begin{array}{l}192.168 .3 .1- \\
192.168 .3 .126\end{array}$ & 192.168 .3 .0 & 192.168 .3 .127 & 255.255 .255 .128 \\
\hline
\end{tabular}

\section{RESUlTS AND DisCUSSION}

Simulations were obtained from this study were performed on a Cisco Packet Tracer 6.0.1 for each routing protocol. Scenario testing is made by using the following ways:

1) Observing delay delivery of data packets from a PC to another PC when traffic is busy.

2) Observing the usual trace route path pass data packets during transmission, and then break the link that bypassed the usual data packets to determine these differences are skipped.

\section{B. First Scenario}

The first scenario testing done by sending the package Internet Control Message Protocol (ICMP) traffic is busy at

\begin{tabular}{|c|c|c|c|c|c|c|c|c|c|}
\hline \multicolumn{2}{|c|}{ Subject 1} & \multicolumn{2}{|c|}{ Subject 2} & \multicolumn{2}{|c|}{ Subject 3} & \multicolumn{2}{|c|}{ Subject 4} & \multicolumn{2}{|c|}{ Subject 5} \\
\hline $\begin{array}{l}\text { Sen } \\
\text { der }\end{array}$ & $\begin{array}{l}\text { Rece } \\
\text { iver }\end{array}$ & $\begin{array}{l}\text { Sen } \\
\text { der }\end{array}$ & $\begin{array}{c}\text { Recei } \\
\text { ver }\end{array}$ & $\begin{array}{l}\text { Sen } \\
\text { der }\end{array}$ & $\begin{array}{c}\text { Recei } \\
\text { ver }\end{array}$ & $\begin{array}{l}\text { Sen } \\
\text { der }\end{array}$ & $\begin{array}{c}\text { Recei } \\
\text { ver }\end{array}$ & $\begin{array}{l}\begin{array}{l}\text { Sen } \\
\text { der }\end{array} \\
\end{array}$ & $\begin{array}{c}\text { Recei } \\
\text { ver }\end{array}$ \\
\hline $\begin{array}{l}\mathrm{PC} \\
0\end{array}$ & PC 5 & $\begin{array}{l}\mathrm{PC} \\
1\end{array}$ & PC 2 & $\begin{array}{l}\mathrm{PC} \\
2\end{array}$ & PC 4 & $\begin{array}{l}\mathrm{PC} \\
4\end{array}$ & PC 7 & $\begin{array}{l}\mathrm{PC} \\
6 \\
\end{array}$ & PC 5 \\
\hline $\begin{array}{l}\mathrm{PC} \\
1 \\
\end{array}$ & PC 2 & $\begin{array}{l}\mathrm{PC} \\
2 \\
\end{array}$ & PC 4 & $\begin{array}{l}\mathrm{PC} \\
4\end{array}$ & PC 7 & $\begin{array}{l}\text { PC } \\
6\end{array}$ & PC 5 & $\begin{array}{l}\mathrm{PC} \\
0\end{array}$ & PC 5 \\
\hline $\begin{array}{l}\text { PC } \\
2\end{array}$ & PC 4 & $\begin{array}{l}\mathrm{PC} \\
4\end{array}$ & PC 7 & $\begin{array}{l}\mathrm{PC} \\
6\end{array}$ & PC 5 & $\begin{array}{l}\mathrm{PC} \\
0\end{array}$ & PC 5 & $\begin{array}{l}\mathrm{PC} \\
1\end{array}$ & PC 2 \\
\hline $\begin{array}{l}\mathrm{PC} \\
4 \\
\end{array}$ & PC 7 & $\begin{array}{l}\mathrm{PC} \\
6 \\
\end{array}$ & PC 5 & $\begin{array}{l}\mathrm{PC} \\
0 \\
\end{array}$ & PC 5 & $\begin{array}{l}\mathrm{PC} \\
1 \\
\end{array}$ & PC 2 & $\begin{array}{l}\mathrm{PC} \\
2 \\
\end{array}$ & PC 4 \\
\hline $\begin{array}{l}\text { PC } \\
6\end{array}$ & PC 5 & $\begin{array}{l}\mathrm{PC} \\
0\end{array}$ & PC 5 & $\begin{array}{l}\mathrm{PC} \\
1\end{array}$ & PC 2 & $\begin{array}{l}\text { PC } \\
2\end{array}$ & PC 4 & $\begin{array}{l}\mathrm{PC} \\
4\end{array}$ & PC 7 \\
\hline
\end{tabular}
the moment as many as five cases and every case the experiment is repeated five times, to increase the traffic on the network added four ICMP packets with the same conditions for each case. 5 cases were simulated apply to a ring topology.

Scenario sending data from PC to PC are shown in the following tables.

TABLE III. SCENARIO OF SENDING DATA PACKETS 
The examined packet is the first packet in table 3 or grayscale line. Other packets are packets sent to improve traffic on the network.

The topology tested using EIGRP and OSPF routing protocol. A delay on the results of these observations is obtained by dividing the second time resulting from the simulation. The chart comparisons of the average delay with these cases are used are as shown below:

TABLE IV. THE AVERAGE SCORE OF THE RING DELAY EIGRP AND OSPF

\begin{tabular}{|c|c|c|c|c|c|}
\hline \multicolumn{5}{|c|}{ Comparison of the average value of delay (seconds) } \\
\hline $\begin{array}{c}\text { Topology } \\
\text { and } \\
\text { routing } \\
\text { protocol }\end{array}$ & $\mathbf{1}$ & $\mathbf{2}$ & $\mathbf{3}$ & $\mathbf{4}$ & $\mathbf{5}$ \\
\cline { 2 - 7 } & \multicolumn{5}{|c|}{ Cases } \\
\hline $\begin{array}{c}\text { Ring } \\
\text { EIGRP }\end{array}$ & 0,012505 & 0,01033 & 0,010325 & 0,01008 & 0,010715 \\
\hline Ring & 0,01305 & 0,01061 & 0,010715 & 0,010405 & 0,011105 \\
\hline OSPF & 0,0105 &
\end{tabular}

If the averaged value of delay each routing protocol for each case is then obtained:

\section{1) Topology Ring EIGRP}

Average delay EIGRP topology Ring.

$$
\begin{gathered}
\frac{0,012505+0,01033+0,010325+0,01008+0,010715}{5} \\
=0,010791 \text { seconds }
\end{gathered}
$$

2) Ring Topology OSPF

Average delay OSPF topology Ring. $0,01305+0,01061+0,010715+0,010405+0,011105$

$$
=0,011177 \text { seconds }
$$

Ring EIGRP value better than the value 0.000386 seconds Ring OSPF.

\section{Second Scenario}

The second scenario testing is done by looking at the data packet router that passed before the termination of the link, and then decide on a few links that pass the package to determine changes in the path of the data packet.

1) The results of the second scenario testing prior to the termination link

\section{- EIGRP topology Ring}

A route to be taken by ICMP packets for delivery from PC 0 to PC 5 is PC 0 - Switch Student ASM - Router 1, Router 0 Router 2 - Switch Student AIMC - PC 5. It is due to the EIGRP route selection performed by the parameter value different metrics for each track. Metric value calculated from the total path or interface that is passed from source router to the destination router by the following equation:

metric $=256 *\left(\frac{10^{7}}{\text { The minimum bandwidth }}+\frac{\text { total delay }}{10}\right)$

Further explanation of the metric value will be described in Fig. 5 as follows.

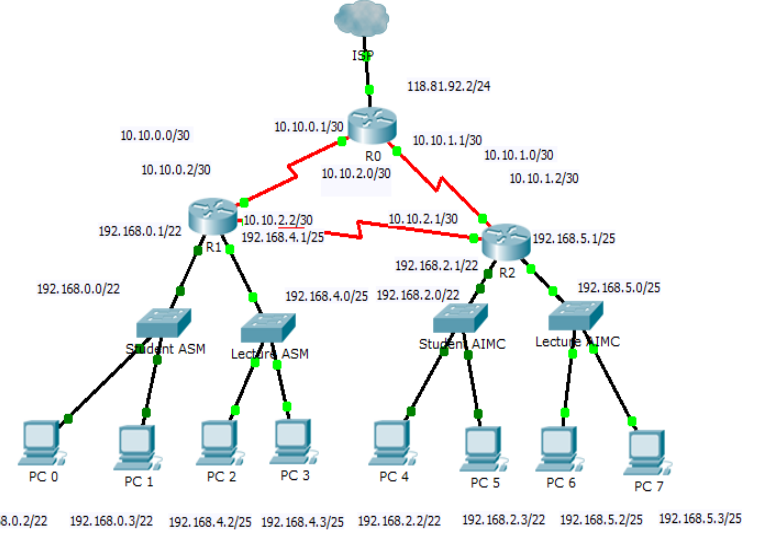

Fig. 5. This packet transmission towards the network from the router 0 Address in a ring topology EIGRP router 1

From fig. 5 above can be seen from the packet transmission path in a router network address 0 towards network address in the router 1 via the router 2 with a minimum bandwidth of $100 \mathrm{kbps}$, delay $20000 \mu \mathrm{s}$ serial interface and fast Ethernet interface $100 \mu$ s delay. Metri-value calculation is as follows:

$$
\begin{aligned}
\text { metric }=256 * & \left(\frac{10^{7}}{100 k b p s}\right. \\
& \left.+\frac{20000 \mu s+20000 \mu s+100 \mu s}{10}\right) \\
& =26626560
\end{aligned}
$$

Meanwhile, if the delivery of network packets at the router address 0 towards the network address in the router 2 via the router 1 with $50 \mathrm{kbps}$ bandwidth, delay $20000 \mu \mathrm{s}$ serial interface and fast Ethernet interface $100 \mu$ s delay. His metric value calculation is as follows:

$$
\begin{aligned}
\text { metric }=256 * & \left(\frac{10^{7}}{50 \mathrm{kbps}}+\frac{20000 \mu \mathrm{s}+20000 \mu \mathrm{s}+100 \mu \mathrm{s}}{10}\right) \\
& =52226560
\end{aligned}
$$

Of the metric calculations can be proven that the data packet will pass 26626560 smallest metric values to reach to the goal than passing the metric value 52226560 larger than the other metrics.

\section{- OSPF topology Ring}

A route to be taken by ICMP packets for delivery from PC 0 to PC 5 is PC 0 - Switch Student ASM - Router 1, Router 0 Router 2 - Switch Student AIMC - PC 5. This is because the OSPF route selection parameter is done by the value of cost which is different for each individual track, cost value is calculated from each or a router interface that is passed from the source to the destination router by the following equation:

$$
\text { Cost }=\frac{100 \mathrm{Mbps}}{\text { Bandwidth }}
$$

Further explanation of the calculation of the cost will be explained in Fig. 6 as follows: 


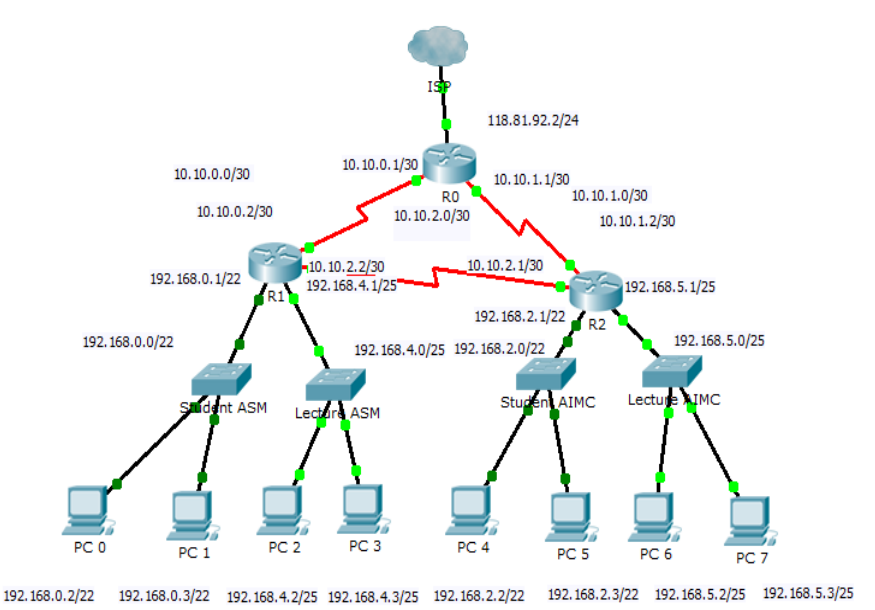

Fig. 6. These routers are sending packets from 0 towards the Ring topology OSPF router 1

From Figure 6 can be seen above the delivery path of network packets at the router address 0 towards network address via the router 1 router 2 with a bandwidth of $100 \mathrm{kbps}$ respectively, its cost value calculation is as follows:

$$
\begin{gathered}
\operatorname{Cost}(\text { total })=\frac{100 \mathrm{Mbps}}{100 \mathrm{kbps}}+\frac{100 \mathrm{Mbps}}{100 \mathrm{kbps}}+\frac{100 \mathrm{Mbps}}{100 \mathrm{Mbps}} \\
=2001
\end{gathered}
$$

So the cost is the interface into the router 1, 2001. Meanwhile, if the deliveries of network packets at the router address 0 towards network address via the router 1 router 2 with each interface bandwidth of $50 \mathrm{kbps}$, its cost value calculation is as follows:

$$
\begin{aligned}
& \operatorname{Cost}(\text { total })=\frac{100 \mathrm{Mbps}}{50 \mathrm{kbps}}+\frac{100 \mathrm{Mbps}}{50 \mathrm{kbps}}+\frac{100 \mathrm{Mbps}}{100 \mathrm{Mbps}} \\
&=4001
\end{aligned}
$$

So the cost towards the router interface 2 is 4001 . From the calculation of the cost can be proved that the data packets passing through the smallest cost value in 2001 to reach to the destination of the passing greater cost that is worth 4001 .

2) The second scenario test results after the termination of the link

After knowing the path data packets Ping ICMP data on the usual channels bypassed disconnected to determine the backup path of each routing protocol at each topology. Disconnected paths are paths that connect the router to router 2. 0 . The result is as follows:

\section{- EIGRP topology Ring}

Once the link is decided on the route that bypassed the PC 0 to PC 5 is PC 0 - Switch Student ASM - Router 1, Router 0 Router 2 - Switch Student AIMC - PC 5. The data packet will pass 52.22656 million metric values.

\section{- OSPF topology Ring}

Once the link is decided on the route that bypassed the PC 0 to PC 5 is PC 0 - Switch Student ASM - Router 1, Router 0 Router 2 - Switch Student AIMC - PC 5. The data packet will pass the cost value of 4001 .

\section{Convergence Time}

In the third scenario, it will be examined i.e. the convergence time for each router to get the information from other routers and ready to transmit data packets.

\section{1) Time ring topology convergence EIGRP}

\begin{tabular}{|c|c|c|c|c|c|c|c|c|}
\hline \multicolumn{9}{|c|}{ IP-EIGRP neighbors for process 1} \\
\hline H & Addresg & Interface & & Uptime & $\begin{array}{l}\text { SRIT } \\
\text { (ms) }\end{array}$ & RTO & $\begin{array}{c}\ell \\
\text { Cnt }\end{array}$ & $\begin{array}{l}\text { Seq } \\
\text { Num }\end{array}$ \\
\hline 0 & 10.10 .0 .2 & $\mathrm{Se} 0 / 1 / 0$ & 13 & $00: 00: 49$ & 40 & 1000 & 0 & 12 \\
\hline 1 & 10.10.1.2 & $\mathrm{Se} 0 / 1 / 1$ & 14 & $00: 00: 10$ & 40 & 1000 & 1 & 0 \\
\hline
\end{tabular}

To determine the Ring EIGRP convergence time can be done by the command "show ip EIGRP neighbors" in the CLI command in every router that result as fig. 7 below:

Fig. 7. Time convergence of simulation results EIGRP topology Ring

Column Hold (sec) which indicates the Hold Time column on the router to wait for the Hello packet from the router to another time when convergence is what underlies every router where the Hello interval by default 5 seconds and Hold / Dead default interval is 15 seconds. So that the average convergence for each router is:

\section{Average Convergence Time}

$=\frac{13+14+14}{3}=13,66$ seconds

2) Time ring topology convergence $O S P F$

To determine the Ring OSPF convergence time can be done by the command "show ip OSPF neighbors" on each router CLI Command that the results as follows:

\begin{tabular}{|lrllll|}
\hline Neighbor ID & Pri & State & Dead Time & Address & Interface \\
118.81 .92 .2 & 0 & FULL $/$ & $00: 00: 33$ & 10.10 .0 .1 & Seria10/1/0 \\
192.168 .5 .1 & 0 & FULL - & $00: 00: 31$ & 10.10 .2 .1 & Seria10/1/1 \\
\hline
\end{tabular}

Fig. 8. Left Ring topology convergence of simulation results OSPF

Dead Time column where the column shows Dead Time on the router to wait for the Hello packet from another router by default Hello interval is 10 seconds and Hold/Dead interval by default 40 seconds. So that the average times for each router convergence are:

Average Convergence Time

$$
=\frac{30+33+37}{3}=33,33 \text { seconds }
$$

\section{CONCLUSION AND SUGGESTIONS}

\section{A. Conclusion}

The results of testing Ring network topology on EIGRP and OSPF routing protocol has the following conclusions.

1) In a ring topology testing the score of total delay EIGRP better than $386 \mu$ seconds delay value in OSPF.

2) OSPF is a link-state so that at the same cost value of the package to be delivered is not always the shortest route but also the longest route. 
3) The average convergence time in a ring topology is 12.75 seconds EIGRP and OSPF Ring topology is 35.25 seconds.

4) The dead-time interval is 15 seconds while the EIGRP OSPF so time is 40 seconds faster than the convergence EIGRP OSPF.

\section{B. Suggestions}

Based on the research results, there are some suggestions:

\section{1) Other researcher}

Other researchers can conduct the same field with different setting and subjects. They also can use it as reference.

2) Simulation computer network is one way to design a computer network before building a computer network in real. REFERENCES

[1] A. Setiawan and N. Sevani, "Perbandingan Quality Of Service Antara Routing Information Protocol ( Rip ) Dengan Open Shortest Path First ( Ospf )," pp. 196-207.

[2] E. Menggunakan, S. Jaringan, and O. Modeler, "Simulasi Kinerja Routing Protokol Open Shortest Path First (Ospf) Dan Enhanced Interior Gateway Routing Protocol (Eigrp) Menggunakan Simulator Jaringan Opnet Modeler v. 14.5," pp. 1-6.

[3] "Pengembangan Jaringan Komputer Universitas Surakarta Berdasarkan Perbandingan Protokol Routing Information Protokol (RIP) Dan Protokol Open Shortest Path First (OSPF) Prawido Utomo, Bambang Eka Purnama ABSTRAKSI,” vol. 1, no. November, pp. 8-25, 2012.
[4] “Desain Implementasi Routing Jaringan Komputer," vol. 3, no. 1, 2009.

[5] B. A. Y. Tampi, M. E. I. Najoan, A. A. E. Sinsuw, A. S. M. Lumenta, and A. P. J. Komputer, "Implementasi Routing Pada IP Camera Untuk Monitoring Ruang di Universitas Sam Ratulangi,” pp. 1-8, 2013.

[6] D. B. Saptonugroho, D. B. P, and B. Santosa, "Analisis Pengaruh Konfigurasi Eigrp Equal Dan Unequal Cost Load Balancing Terhadap Kinerja Router."

[7] J. Jenderal, A. Yani, and N. Palembang, "Analisis Kinerja Routing Protocol Rip Pada Jaringan IPV4 DAN IPV6,” vol. 6, no. 12, pp. 1-10.

[8] D. S. Bataona, G. C. Manulangga, and K. Kunci, "Analisis dan Perancangan Metode Subnetting: Hybrid Fixed Length Subnet Masking ( HFLSM )," vol. 2, no. 2, pp. 7-15, 2014.

[9] Tina Fajrin, Bambang Eka Purnama, Analisis Sistem Penyimpanan Data Menggunakan Sistem Cloud Computing Studi Kasus SMK N 2 Karanganyar, Seruni 2012 - Seminar Riset Unggulan Nasional Informatika dan Komputer

[10] Wiji Suhardjo, Bambang Eka Purnama (2013), Pemanfaatan Local Area Network Dan Program Netop School Sebagai Media Pembelajaran Interaktif Pada Jurusan Teknik Komputer Jaringan Smk N 1 Klaten, IJNS - Indonesian Journal on Networking and Security, Vol 2 No 3 Juli 2013, ijns.org, ISSN: 2302-5700

[11] Muchamad Arifin, Ramadhian Agus Triyono, Rekayasa dan Manajemen Jaringan WAN SMK Alhikmah Tanon, IJNS - Indonesian Journal on Networking and Security, Vol 2 No 1 - Januari 2013, ijns.org, ISSN: 2302-5700

[12] Muhammad Taufiq Muslih, Bambang Eka Purnama, Pengembangan Aplikasi Sms Gateway Untuk Informasi Pendaftaran Peserta Didik Baru Di SMAN 1 Jepara, IJNS - Indonesian Journal on Networking and Security, Vol 2 No 1 - Januari 2013, ijns.org, ISSN: 2302-5700 